\title{
Investigation of metal-buffer interactions using isothermal titration calorimetry
}

\author{
D. Wyrzykowski • B. Pilarski • D. Jacewicz • \\ L. Chmurzyński
}

Received: 10 May 2012/Accepted: 9 July 2012/Published online: 1 September 2012

(C) The Author(s) 2012. This article is published with open access at Springerlink.com

\begin{abstract}
Isothermal titration calorimetry (ITC) and potentiometric titration (PT) methods were used to study the interactions of cobalt(II) and nickel(II) ions with buffer substances 2-( $N$-morpholino)ethanesulfonic acid (Mes), dimethylarsenic acid (Caco), and piperazine- $N, N^{\prime}$-bis (2-ethanesulfonic acid) (Pipes). Based on the results of PT data, the stability constants were calculated for the metal-buffer complexes $(T=298.15 \mathrm{~K}$, ionic strength $I=100 \mathrm{mM} \mathrm{NaClO}$ ). Furthermore, calorimetric measurements (ITC) were run in $100 \mathrm{mM}$ Mes, Caco, and Pipes solutions with $\mathrm{pH} 6$, at $298.15 \mathrm{~K}$. The enthalpies $(\Delta H)$ of the metalbuffer complexation reactions were calculated indirectly by displacement titration using nitrilotriacetic acid $\left(\mathrm{H}_{3} \mathrm{NTA}\right)$ as a strong-binding, competitive ligand. Finally, to verify obtained results, the number of protons released by $\mathrm{H}_{3} \mathrm{NTA}$ due to complexation of the cobalt(II) and nickel(II) ions was determined from calorimetric data and compared with results of calculations.
\end{abstract}

Keywords Isothermal titration calorimetry .

Metal-buffer interactions - Potentiometric titration .

Proton exchange $\cdot$ Thermodynamic parameters

Electronic supplementary material The online version of this article (doi:10.1007/s10973-012-2593-y) contains supplementary material, which is available to authorized users.

D. Wyrzykowski $(\bowtie) \cdot$ D. Jacewicz $\cdot$ L. Chmurzyński

Faculty of Chemistry, University of Gdańsk, Sobieskiego 18, 80-952 Gdańsk, Poland

e-mail: daro@chem.univ.gda.pl

B. Pilarski

P.P.H.U. Cerko s.c, Afrodyty 9, 80-299 Gdańsk, Poland

\section{Introduction}

Most of the biological and biochemical processes are proton-donor or proton-acceptor type of reaction. For this reason, biochemical experiments are usually carried out in a buffer solution $[1,2]$. The same mechanism takes place during calorimetric measurements when the binding enthalpy (under isobaric conditions) is directly measured. Calorimetric methods such as the isothermal titration calorimetry (ITC) are now widely used to quantify stoichiometry, binding constants, and thermodynamics on the field of life science investigations (http://www.microcal.com/ reference-center/reference-list.asp).

When a reaction involves the release (or uptake) of protons, additional heat is usually generated. This heat (thermal effect) is not connected with intermolecular interactions and should be taken into account while interpreting calorimetric data. The situation is slightly more complicated when metal ions are involved in biological processes [3-7]. In such cases, to determine conditionindependent thermodynamic values $(K, \Delta H)$, the effect of buffer competition with the ligand for the metal as well as proton competition with the metal for the ligand must be taken into consideration.

2-( $N$-Morpholino)ethanesulfonic acid (Mes), dimethylarsenic acid (Caco), and piperazine- $N, N^{\prime}$-bis(2-ethanesulfonic acid) (Pipes) (Fig. 1) are the buffer substances widely used in biological experiments as well as in calorimetric studies [8]. However, to the best of our knowledge, there are few reports on the interactions of such buffers with metal ions. This was, among others, the main reason that prompted us to embark on these studies.

In this article, thermodynamic parameters for complexation reactions of the $\mathrm{Co}^{2+}$ and $\mathrm{Ni}^{2+}$ ions with Mes, Pipes, and Caco buffer are presented. Metal-buffer (Mes, Pipes, 


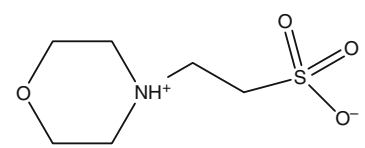

Mes, 2-(N-morpholino)ethanesulfonic acid

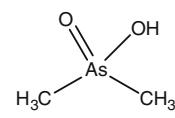

Caco, dimethylarsenic aci

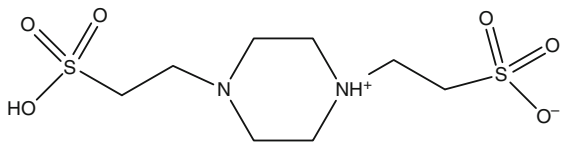

Pipes, piperazine-N,N'-bis(2-ethanesulfonic acid)

Fig. 1 Buffer substances used in this study

Caco) formation constants were determined by potentiometric titration (PT). Then, the enthalpies of the metalbuffer interaction were determined by displacement titration using the ITC technique [9]. Nitrilotriacetic acid $\left(\mathrm{H}_{3} \mathrm{NTA}\right)$ was used in the displacement experiments as a strong-binding, competitive ligand. Finally, the effect of $\mathrm{pH}$ and the type of buffer on the enthalpy reaction and the stability constants of the resulting complexes were discussed.

\section{Experimental}

\section{Materials}

All reagents, namely 2-( $N$-morpholino)ethanesulfonic acid hydrate $(\geq 99 \%)$ (Mes), dimethylarsenic acid $(\geq 99 \%)$ (Caco), piperazine- $N, N^{\prime}$-bis(2-ethanesulfonic acid) ( $\geq 99 \%$ ) (Pipes), $\mathrm{Co}\left(\mathrm{NO}_{3}\right)_{2} \cdot 6 \mathrm{H}_{2} \mathrm{O}(\geq 99 \%), \mathrm{Ni}\left(\mathrm{NO}_{3}\right)_{2} \cdot 6 \mathrm{H}_{2} \mathrm{O}(\geq 99.9$ $99 \%), \mathrm{H}_{3} \mathrm{NTA}(\geq 99 \%), \mathrm{HClO}_{4}$, and $\mathrm{NaClO}_{4}$ were purchased from Sigma-Aldrich Chemical Corp. and used as received. Double distilled water with conductivity not exceeding $0.18 \mu \mathrm{S} \mathrm{cm}^{-1}$ was used for preparation of aqueous solutions of titrant and titrand.

\section{Isothermal titration calorimetry}

All ITC experiments were performed at $298.15 \mathrm{~K}$ using an AutoITC isothermal titration calorimeter (MicroCal Inc. GE Healthcare, Northampton, USA) with a $1.4491 \mathrm{~mL}$ sample and the reference cells. The reference cell contained distilled water. The data, specifically the heat normalized per mole of injectant, were processed with Origin 7 from MicroCal. An initial $2 \mu \mathrm{L}$ injection was discarded from each data set to remove the effect of titrant diffusion across the syringe tip during the equilibration process. All reagents were dissolved directly into $100 \mathrm{mM}$ buffer solution of Mes, Caco, or Pipes. The $\mathrm{pH}$ of the buffer solution was adjusted to 6 with $0.1 \mathrm{M} \mathrm{HClO}_{4}$. The experiment consisted of injecting $10.02 \mu \mathrm{L}$ (29 injections, $2 \mu \mathrm{L}$ for the first injection only) of ca $5 \mathrm{mM}$ buffered solution of $\mathrm{H}_{3} \mathrm{NTA}$ into the reaction cell which initially contained ca $0.25-0.5 \mathrm{mM}$ buffered solution of suitable salt. A background titration, consisting of an identical titrant solution but with the buffer solution in the reaction cell only, was removed from each experimental titration to account for the heat of dilution. All the solutions were degassed prior to titration. The titrant was injected at 5-min interval to ensure that the titration peak returned to the baseline before the next injection. Each injection lasted $20 \mathrm{~s}$. For homogeneous mixing in the cell, the stirrer speed was kept constant at $300 \mathrm{rpm}$. Calibration of the AutoITC calorimeter was carried out electrically by using electrically generated heat pulses. The $\mathrm{CaCl}_{2}$-EDTA titration was performed to check the apparatus and the results ( $n-$ stoichiometry, $K, \Delta H$ ) were compared with those obtained for the same samples (test kit) at MicroCal.

\section{Potentiometric measurements}

PTs were performed in $30 \mathrm{~mL}$ thermostated $(298.15 \pm$ $0.10 \mathrm{~K}$ ) cell using Cerko Lab System microtitration unit fitted with $0.5-\mathrm{mL}$ Hamilton's syringe, $\mathrm{pH}$ combined electrode (Schott - BlueLine $16 \mathrm{pH}$ type) and a self-made measuring cell equipped with magnetic stirrer. The temperature was controlled using the Lauda E100 circulation thermostat. The electrode was calibrated according to IUPAC recommendations [10]. Syringe was calibrated by weight method. All the solutions were prepared immediately before measurements (ionic strength $I=100 \mathrm{mM}$ $\mathrm{NaClO}_{4}$ ). The compositions of the titrand solutions used in the experiments were as follows: (1) Mes (18.16 mM) and $\mathrm{HClO}_{4}(3.11 \mathrm{mM})$, (2) Caco $(10.01 \mathrm{mM})$ and $\mathrm{HClO}_{4}$ (3.10 mM), (3) Pipes $(2 \mathrm{mM}),(4) \mathrm{Co}^{2+}(2.49 \mathrm{mM})$, Mes $(18.16 \mathrm{mM})$, and $\mathrm{HClO}_{4}(3.11 \mathrm{mM}),(5) \mathrm{Ni}^{2+}(2.46 \mathrm{mM})$, Mes $(18.16 \mathrm{mM})$, and $\mathrm{HClO}_{4}(3.11 \mathrm{mM})$, (6) $\mathrm{Co}^{2+}$ $(1.97 \mathrm{mM})$, Caco $(10.01 \mathrm{mM})$, and $\mathrm{HClO}_{4}(3.10 \mathrm{mM})$, (7) $\mathrm{Ni}^{2+}(1.95 \mathrm{mM})$, Caco $(10.01 \mathrm{mM})$, and $\mathrm{HClO}_{4}$ (3.10 mM), (8) $\mathrm{Co}^{2+}(1.68 \mathrm{mM})$, Pipes $(2 \mathrm{mM}),(9) \mathrm{Ni}^{2+}$ (1.69 mM), Pipes (2.00 mM), and (10) $\mathrm{H}_{3}$ NTA (2.01 mM). The solutions were potentiometrically titrated with a standardized $\mathrm{KOH}$ solution $(100.43 \mathrm{mM})$ with $\mathrm{pH}$ ranging from 2.5 to 12.0 . The stability constants of the complexes were determined using CVEQUID program [11] by minimization of the differences between the theoretical model and the experimental data, according to Gauss-NewtonMarquart for nonlinear equations (see Ref. [12] for more details). The original CVEQUID algorithm was combined with CerkoLab software. After titration the acquired data was processed and the equilibria model was symbolically described by set of equations. The formalism used to define a " $\mathrm{p} K$ model" was based on a simplified way customary 
used to describe equilibrium state in the mixture. To further simplify the preparation of data required for numerical procedures the " $\mathrm{p} K$ model" included statements describing the composition of titrant, titrand, electrode parameters, and solvent. The stoichiometric matrix required for the procedure was automatically generated from the model.

\section{Results and discussion}

The conditions under which ITC experiments are carried out influence both the binding constants $(K)$ and the enthalpies $(\Delta H)$ of the reaction. To compare ITC thermodynamic values with other methods one should take into account the $\mathrm{pH}$, temperature as well as the kind of buffer solution in which the measurements are done. In systems where metal ions (M) are involved, metal-buffer complex formation must also be considered during ITC data analysis.

To determine thermodynamic values $(K, \Delta H)$ of metalbuffer interactions, displacement ITC experiments were carried out. Thus, a weak ligand (buffer Mes, Caco, or Pipes) was replaced by a strong one in the coordination sphere of the central ion. $\mathrm{H}_{3}$ NTA was used in our study as the strong-binding, competitive ligand. The nitrilotriacetate ions $\left(\mathrm{NTA}^{3-}\right)$ act as tetradentate ligands and form 1:1 metal-ligand complexes (ML) with most ions [13, 14]. Oxygen atoms of three carboxylic groups and a central nitrogen atom participate in the metal binding (Fig. 2). Moreover, the acid-base dissociation constants of $\mathrm{H}_{3}$ NTA, the enthalpies of proton-ligand dissociation as well as the enthalpies of complexation of cobalt(II) and nickel(II) ions with $\mathrm{H}_{3}$ NTA are known [15]. These values are required to determine the thermodynamic values of metal-buffer interactions by a displacement ITC experiment [9].

$\mathrm{H}_{3}$ NTA is a weak triprotonated acid which dissociates in three steps presented by Eqs. 1-3:

$$
\begin{aligned}
& \mathrm{H}_{3} \mathrm{NTA}=\mathrm{H}_{2} \mathrm{NTA}^{-}+\mathrm{H}^{+} \quad K_{\mathrm{a} 1}=\frac{\left[\mathrm{H}_{2} \mathrm{NTA}^{-}\right]\left[\mathrm{H}^{+}\right]}{\left[\mathrm{H}_{3} \mathrm{NTA}\right]} \\
& \mathrm{H}_{2} \mathrm{NTA}^{-}=\mathrm{HNTA}^{2-}+\mathrm{H}^{+} \quad K_{\mathrm{a} 2}=\frac{\left[\mathrm{HNTA}^{2-}\right]\left[\mathrm{H}^{+}\right]}{\left[\mathrm{H}_{2} \mathrm{NTA}^{-}\right]}
\end{aligned}
$$

$\mathrm{HNTA}^{2-}=\mathrm{NTA}^{3-}+\mathrm{H}^{+} \quad K_{\mathrm{a} 3}=\frac{\left[\mathrm{NTA}^{3-}\right]\left[\mathrm{H}^{+}\right]}{\left[\mathrm{HNTA}^{2-}\right]}$

At $298.15 \mathrm{~K}$ equilibrium constants $\mathrm{p} K_{\mathrm{a} 1}, \mathrm{p} K_{\mathrm{a} 2}$, and $\mathrm{p} K_{\mathrm{a} 3}$ are 1.68-2.08, 2.67-2.95, and 9.49-9.95, respectively [15]. For calculations, we used the $\mathrm{p} K_{\mathrm{a} 1}, \mathrm{p} K_{\mathrm{a} 2}$, and $\mathrm{p} K_{\mathrm{a} 3}$ values obtained in our laboratory. They are as follows: $\mathrm{p} K_{\mathrm{a} 1}=2.28$ ( \pm 0.17$), \mathrm{p} K_{\mathrm{a} 2}=2.88( \pm 0.19)$, and $\mathrm{p} K_{\mathrm{a} 3}=9.55( \pm 0.07)$.

The concentration of $\mathrm{H}_{3} \mathrm{NTA}$ is equal to the sum of the concentrations of all the particular components involved in equilibrium (Eq. 4). The concentration of these chemical species depends on the $\mathrm{pH}$ of a solution.

$\begin{aligned} c_{\mathrm{H}_{3} \mathrm{NTA}}= & {\left[\mathrm{NTA}^{3-}\right]+\left[\mathrm{HNTA}^{2-}\right]+\left[\mathrm{H}_{2} \mathrm{NTA}^{-}\right] } \\ & +\left[\mathrm{H}_{3} \mathrm{NTA}\right] .\end{aligned}$

Knowing the $\mathrm{p} K_{\mathrm{a}}$ values of $\mathrm{H}_{3}$ NTA and using appropriate formulas (Eqs. 5a-5c) one can find an expression that describes the relationship between the $\mathrm{pH}$ of a solution and the stability constant (Eq. 6).

$$
\begin{aligned}
c_{\mathrm{H}_{3} \mathrm{NTA}} & =\left[\mathrm{NTA}^{3-}\right]+\left[\mathrm{HNTA}^{2-}\right]+\left[\mathrm{H}_{2} \mathrm{NTA}^{-}\right]+\left[\mathrm{H}_{3} \mathrm{NTA}\right] \\
& =\left[\mathrm{NTA}^{3-}\right]\left(1+\frac{\left[\mathrm{H}^{+}\right]}{K_{\mathrm{a} 3}}+\frac{\left[\mathrm{H}^{+}\right]^{2}}{K_{\mathrm{a} 3} \cdot K_{\mathrm{a} 2}}+\frac{\left[\mathrm{H}^{+}\right]^{3}}{K_{\mathrm{a} 3} \cdot K_{\mathrm{a} 2} \cdot K_{\mathrm{a} 1}}\right)
\end{aligned}
$$

$\alpha_{\text {proton }}=1+\frac{\left[\mathrm{H}^{+}\right]}{K_{\mathrm{a} 3}}+\frac{\left[\mathrm{H}^{+}\right]^{2}}{K_{\mathrm{a} 3} \cdot K_{\mathrm{a} 2}}+\frac{\left[\mathrm{H}^{+}\right]^{3}}{K_{\mathrm{a} 3} \cdot K_{\mathrm{a} 2} \cdot K_{\mathrm{a} 1}}$

$c_{\mathrm{H}_{3} \mathrm{NTA}}=\left[\mathrm{NTA}^{3-}\right] \cdot \alpha_{\text {proton }}$

$K_{\mathrm{ITC}}=\frac{[\mathrm{MNTA}]}{[\mathrm{M}] \cdot c_{\mathrm{H}_{3} \mathrm{NTA}}}=\frac{[\mathrm{MNTA}]}{[\mathrm{M}][\mathrm{NTA}]} \cdot \frac{1}{\alpha_{\text {proton }}}=K_{\mathrm{MNTA}} \cdot \frac{1}{\alpha_{\text {proton }}}$

where $\mathrm{M}$ denotes metal ion, $K_{\mathrm{ITC}}$ is the conditional (observed) binding constant obtained directly from the ITC experiment. $K_{\text {ITC }}$ depends on the $\mathrm{pH}$ of a solution and the $\mathrm{p} K_{\mathrm{a}}$ values of a ligand (as well as ionic strength and temperature), $\alpha_{\text {proton }}$ is the function of $\mathrm{pH}$ and $\mathrm{p} K_{\mathrm{a}}$ 's, $K_{\mathrm{MNTA}}$ is the $\mathrm{pH}$-independent metal $\left(\mathrm{M}^{2+}\right)$-ligand $\left(\mathrm{NTA}^{3-}\right)$ binding constant $\left(\mathrm{M}^{2+}+\mathrm{NTA}^{3-}=\mathrm{MNTA}^{-}\right)$and can be compared to $K$ values obtained by other methods. It can also be extrapolated to different conditions.
Fig. 2 The coordination mode of metal(II) ion to nitrilotriacetate anion $\left(\mathrm{NTA}^{3-}\right)$

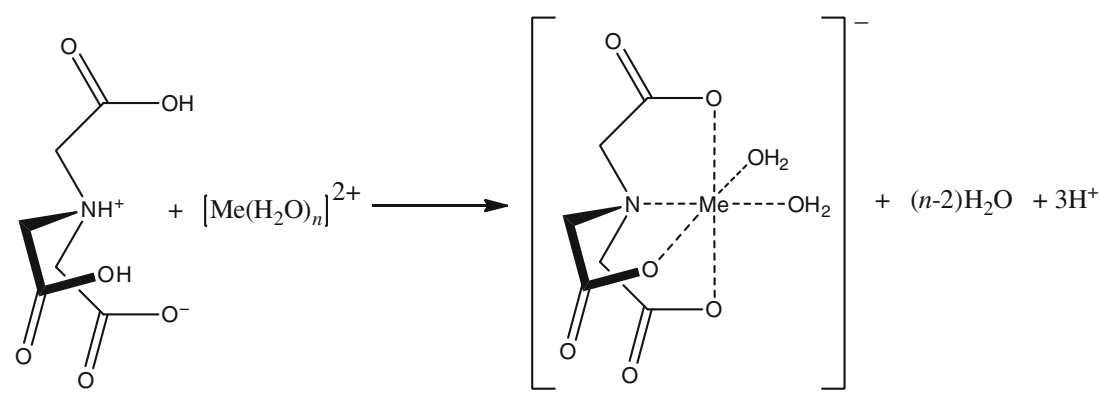


The situation is slightly more complicated when metal ions are involved in the system under study. If one assumes that the metal ions (M) with buffer type of $\mathrm{H}_{n} \mathrm{~B}$ form complexes having a molar metal to ligand ratio of 1:1 (MB) the following equations should be used during calorimetric data analysis (Eqs. 7a-7c):

$$
\begin{aligned}
\mathrm{M}+\mathrm{B} & =\mathrm{MB} \quad K_{\mathrm{MB}}=\frac{[\mathrm{MB}]}{[\mathrm{M}][\mathrm{B}]} \\
{[\mathrm{M}]_{\mathrm{ITC}} } & =[\mathrm{M}]+[\mathrm{MB}]=[\mathrm{M}]+K_{\mathrm{MB}}[\mathrm{M}][\mathrm{B}] \\
& =[\mathrm{M}]\left(1+K_{\mathrm{MB}}[\mathrm{B}]\right) \\
{[\mathrm{M}]_{\mathrm{ITC}} } & =[\mathrm{M}] \cdot \alpha_{\text {buffer }}
\end{aligned}
$$

where $[\mathrm{M}]_{\text {ITC }}$ indicates the concentration of the metal species not involved in the MB complex, $K_{\mathrm{MB}}$ indicates the stability constant for the metal-buffer complex (MB), [B] indicates the concentration of a buffer solution, $\alpha_{\text {buffer }}=1+K_{\mathrm{MB}}[\mathrm{B}]$ is a function of the $K_{\mathrm{MB}}$ and [B].

In such a case, to determine the $\mathrm{pH}$ and buffer-independent stability constant $K_{\text {MNTA }}$ the following equation must be applied (Eq. 8):

$$
\begin{aligned}
K_{\text {ITC }} & =\frac{[\mathrm{ML}]}{[\mathrm{M}]_{\text {ITC }} c_{\mathrm{H}_{3} \mathrm{NTA}}}=\frac{[\mathrm{ML}]}{[\mathrm{M}][\mathrm{L}]} \cdot \frac{1}{\alpha_{\text {proton }} \cdot \alpha_{\text {buffer }}} \\
& =\frac{K_{\mathrm{MNTA}}}{\alpha_{\text {proton }} \cdot \alpha_{\text {buffer }}}
\end{aligned}
$$

which finally leads to an expression (Eq. 9) for the condition-independent $K_{\mathrm{MNTA}}$ :

$K_{\mathrm{MNTA}}=K_{\mathrm{ITC}} \cdot \alpha_{\text {proton }} \cdot \alpha_{\text {buffer }}$

The assumption that in the systems under study, 1:1 metal-buffer complexes (MB) are formed, was verified by
PT. The following equilibria were assumed and used to calculate the metal-buffer stability constants.

Equilibrium models for interactions of the metal ions (M) with the Mes or Caco buffers (HB):

$$
\begin{aligned}
\mathrm{HB} & =\mathrm{B}^{-}+\mathrm{H}^{+} & & \mathrm{p} K_{\mathrm{a}} \\
\mathrm{M}^{2+}+\mathrm{B}^{-} & =\mathrm{MB}^{+} & & \log K_{\mathrm{MB}} \\
\mathrm{MB}^{+}+2 \mathrm{OH}^{-} & =\mathrm{MB}(\mathrm{OH})_{2}^{-} & & \log K_{\mathrm{MB}(\mathrm{OH})_{2}} \\
\mathrm{H}_{2} \mathrm{O} & =\mathrm{H}^{+}+\mathrm{OH}^{-} & & \mathrm{p} K_{\mathrm{w}}
\end{aligned}
$$

Equilibrium models for interactions of the metal ions (M) with the Pipes buffer $\left(\mathrm{H}_{2} \mathrm{~B}\right)$ :

$$
\begin{aligned}
\mathrm{H}_{2} \mathrm{~B} & =\mathrm{BH}^{-}+\mathrm{H}^{+} & & \mathrm{p} K_{\mathrm{a} 1} \\
\mathrm{BH}^{-} & =\mathrm{B}^{2-}+\mathrm{H}^{+} & & \mathrm{p} K_{\mathrm{a} 2} \\
\mathrm{M}^{2+}+\mathrm{B}^{2-} & =\mathrm{MB} & & \log K_{\mathrm{MB}} \\
\mathrm{MB}+2 \mathrm{OH}^{-} & =\mathrm{MB}(\mathrm{OH})_{2}^{2-} & & \log K_{\mathrm{MB}(\mathrm{OH})_{2}} \\
\mathrm{H}_{2} \mathrm{O} & =\mathrm{H}^{+}+\mathrm{OH}^{-} & & \mathrm{p} K_{\mathrm{w}}
\end{aligned}
$$

\begin{tabular}{|c|c|c|c|}
\hline $\mathrm{p} K$ or $\log K$ & Equilibrium model & $\mathrm{M}^{2+}=\mathrm{Co}^{2+}$ & $\mathrm{M}^{2+}=\mathrm{Ni}^{2+}$ \\
\hline \multicolumn{4}{|l|}{ Mes buffer } \\
\hline $\mathrm{p} K_{\mathrm{a} 1}$ & $\mathrm{MesH}=\mathrm{Mes}^{-}+\mathrm{H}^{+}$ & $6.10( \pm 0.02)$ & $6.11( \pm 0.03)$ \\
\hline $\log K_{\mathrm{MB}}$ & $\mathrm{M}^{2+}+\mathrm{Mes}^{-}=\mathrm{MMes}^{+}$ & $2.04( \pm 0.17)$ & $2.06( \pm 0.19)$ \\
\hline $\log K_{\mathrm{MB}(\mathrm{OH})_{2}}$ & $\mathrm{MMes}^{+}+2 \mathrm{OH}^{-}=\operatorname{MMes}(\mathrm{OH})_{2}^{-}$ & $10.38( \pm 0.09)$ & $10.79( \pm 0.09)$ \\
\hline $\mathrm{p} K_{\mathrm{w}}$ & $\mathrm{H}_{2} \mathrm{O}=\mathrm{OH}^{-}+\mathrm{H}^{+}$ & $13.74( \pm 0.02)$ & $13.76( \pm 0.03)$ \\
\hline \multicolumn{4}{|l|}{ Caco buffer } \\
\hline $\mathrm{p} K_{\mathrm{a} 1}$ & $\mathrm{CacoH}=\mathrm{Caco}^{-}+\mathrm{H}^{+}$ & $6.09( \pm 0.04)$ & $6.13( \pm 0.03)$ \\
\hline $\log K_{\mathrm{MB}}$ & $\mathrm{M}^{2+}+\mathrm{Caco}^{-}=\mathrm{MCaco}^{+}$ & $2.30( \pm 0.22)$ & $2.33( \pm 0.15)$ \\
\hline $\log K_{\mathrm{MB}(\mathrm{OH})_{2}}$ & $\mathrm{MCaco}^{+}+2 \mathrm{OH}^{-}=\mathrm{MCaco}(\mathrm{OH})_{2}^{-}$ & $10.16( \pm 0.10)$ & $10.60( \pm 0.05)$ \\
\hline $\mathrm{p} K_{\mathrm{w}}$ & $\mathrm{H}_{2} \mathrm{O}=\mathrm{OH}^{-}+\mathrm{H}^{+}$ & $13.70( \pm 0.02)$ & $13.71( \pm 0.01)$ \\
\hline \multicolumn{4}{|l|}{ Pipes buffer } \\
\hline $\mathrm{p} K_{\mathrm{a} 1}$ & PipesH $_{2}=$ PipesH $^{-}+\mathrm{H}^{+}$ & $2.61( \pm 0.13)$ & $2.86( \pm 0.15)$ \\
\hline $\mathrm{p} K_{\mathrm{a} 2}$ & PipesH $^{-}=$Pipes $^{2-}+\mathrm{H}^{+}$ & $7.06( \pm 0.09)$ & $7.15( \pm 0.10)$ \\
\hline $\log K_{\mathrm{MB}}$ & $\mathrm{M}^{2+}+$ Pipes $^{2-}=$ MPipes & $3.12( \pm 0.15)$ & $3.20( \pm 0.14)$ \\
\hline $\log K_{\mathrm{MB}(\mathrm{OH})_{2}}$ & MPipes $+2 \mathrm{OH}^{-}=\operatorname{MPipes}(\mathrm{OH})_{2}^{2-}$ & $10.18( \pm 0.07)$ & $10.57( \pm 0.07)$ \\
\hline $\mathrm{p} K_{\mathrm{w}}$ & $\mathrm{H}_{2} \mathrm{O}=\mathrm{OH}^{-}+\mathrm{H}^{+}$ & $13.77( \pm 0.06)$ & $13.76( \pm 0.07)$ \\
\hline
\end{tabular}

The $\mathrm{p} K$ and $\log K$ values of the individual equilibria that contribute to the experimental equilibrium involving a metal (M) binding to a buffer (B), together with their standard deviations, are summarized in Table 1 . The $K_{\mathrm{MB}}$ values obtained from PTs are the pH-independent stability constants and can be extrapolated to the conditions, under which the calorimetric measurements were carried out. The metal-buffer conditional stability constants $K_{\mathrm{MB}}^{\prime}$ at $\mathrm{pH} 6 \quad\left(I=0.100 \mathrm{M} \mathrm{NaClO}{ }_{4}\right)$ were calculated using Eq. 10.

Table $1 \mathrm{p} K$ and $\log K$ values (standard deviation in parentheses) for the metal-buffer interactions in water at $T=298.15 \mathrm{~K}$ (ionic strength $I=0.100 \mathrm{M} \mathrm{NaClO}_{4}$ ) obtained by adapting the equilibrium model to PT data 
Table 2 Individual equilibria that contribute to the overall equilibrium for the formation of metal- $\mathrm{H}_{3} \mathrm{NTA}$ complex in the Mes, Caco, or Pipes buffer solution (B) (the charges of ions are omitted for the sake of clarity)

\begin{tabular}{llll}
\hline No. & Reaction $^{\mathrm{a}}$ & Coefficient & $\Delta H^{\mathrm{b}}$ \\
\hline 1 & $\mathrm{MB}=\mathrm{M}+\mathrm{B}$ & $\alpha_{\mathrm{MB}}$ & $-\Delta H_{\mathrm{MB}}^{\mathrm{o}}$ \\
2 & $\mathrm{HNTA}=\mathrm{NTA}+\mathrm{H}$ & $\alpha_{\mathrm{HNTA}}$ & $-\Delta H_{\mathrm{HNTA}}^{\mathrm{o}}$ \\
3 & $\mathrm{H}_{2} \mathrm{NTA}=\mathrm{NTA}+2 \mathrm{H}$ & $\alpha_{\mathrm{H}_{2} \mathrm{NTA}}$ & $-\Delta H_{\mathrm{H}_{2} \mathrm{NTA}}^{\mathrm{o}}$ \\
4 & $\mathrm{H}_{3} \mathrm{NTA}=\mathrm{NTA}+3 \mathrm{H}$ & $\alpha_{\mathrm{H}_{3} \mathrm{NTA}}$ & $-\Delta H_{\mathrm{H}_{3} \mathrm{NTA}}^{\mathrm{N}}$ \\
5 & $\mathrm{M}+\mathrm{NTA}=\mathrm{MNTA}$ & 1 & $\Delta H_{\mathrm{MNTA}}^{\mathrm{o}}$ \\
6 & $\mathrm{~B}+\mathrm{H}=\mathrm{HB}$ & $\alpha_{\mathrm{HNTA}}+2 \alpha_{\mathrm{H}_{2} \mathrm{NTA}}+3 \alpha_{\mathrm{H}_{3} \mathrm{NTA}}$ & $\Delta H_{\mathrm{BH}}^{\mathrm{o}}$ \\
\hline
\end{tabular}

${ }^{a}$ Equilibria are written in the direction that the reaction occurs (1-4 are dissociations, 5 and 6 are associations)

b $\Delta H^{\mathrm{o}} / \mathrm{kcal} \mathrm{mol}^{-1}$ values are for the association reactions

$K_{\mathrm{MB}}^{\prime}=\frac{[\mathrm{MB}]}{[\mathrm{M}] \cdot c_{\mathrm{B}}}=\frac{[\mathrm{MB}]}{[\mathrm{M}][\mathrm{B}]} \cdot \frac{1}{\alpha_{\text {proton }}}=K_{\mathrm{MB}} \cdot \frac{1}{\alpha_{\text {proton }}}$,

where $c_{\mathrm{B}}$ is the concentration of buffer (B) and equals $c_{\mathrm{B}}=[\mathrm{HB}]+[\mathrm{B}]$ for the Mes and Caco buffer or $c_{\mathrm{B}}=\left[\mathrm{H}_{2} \mathrm{~B}\right]+[\mathrm{HB}]+[\mathrm{B}]$ for the Pipes buffer.

To find $\alpha_{\text {proton }}$ (Eq. $5 \mathrm{~b}$ ), the values of the acid-based dissociation constants of the buffers were taken from Table 1. The logarithms of the $K_{\mathrm{MB}}^{\prime}$ value equal to 1.68 , 1.95, and 2.03 for the Co-Mes, Co-Caco, and Co-Pipes complex, respectively, and $1.69,1.96$, and 2.03 for the $\mathrm{Ni}-$ $\mathrm{Mes}, \mathrm{Ni}-\mathrm{Caco}$, and Ni-Pipes complex, respectively. Then, the $K_{\mathrm{MB}}^{\prime}$ constants were used to determine the enthalpies of the metal-buffer interaction. Assuming, based on potentiometric data, that the $\mathrm{Co}^{2+}$ and $\mathrm{Ni}^{2+}$ ions form 1:1 complexes with buffer (B) as well as taking into account four protonation states of $\mathrm{H}_{3}$ NTA ligand (Eq. 4), the individual equilibria that contribute to the overall equilibrium, as well as the coefficients that indicate the percentage of the particular chemical species in solution under experimental conditions are presented in Table 2. The overall reaction for the formation of metal- $\mathrm{H}_{3} \mathrm{NTA}$ complex is given by general equation 11 .

$$
\begin{aligned}
& \left(1-\alpha_{\mathrm{MB}}\right) \mathrm{M}+\alpha_{\mathrm{MB}} \mathrm{MB}+\left(1-\alpha_{\mathrm{HNTA}}-\alpha_{\mathrm{H}_{2} \mathrm{NTA}}-\alpha_{\mathrm{H}_{3} \mathrm{NTA}}\right) \\
& \quad \times \text { NTA }+\alpha_{\mathrm{HNTA}} \mathrm{HNTA}+\alpha_{\mathrm{H}_{2} \mathrm{NTA}} \mathrm{H}_{2} \mathrm{NTA} \\
& +\alpha_{\mathrm{H}_{3} \mathrm{NTA}} \mathrm{H}_{3} \mathrm{NTA}+\left(\alpha_{\mathrm{HNTA}}+2 \alpha_{\mathrm{H}_{2} \mathrm{NTA}}+3 \alpha_{\mathrm{H}_{3} \mathrm{NTA}}\right) \mathrm{B} \\
& \quad=\text { MNTA }+\left(\alpha_{\mathrm{HNTA}}+2 \alpha_{\mathrm{H}_{2} \mathrm{NTA}}+3 \alpha_{\mathrm{H}_{3} \mathrm{NTA}}\right) \mathrm{BH}
\end{aligned}
$$

In Eq. 11 , the sum $\left(\alpha_{\mathrm{HNTA}}+2 \alpha_{\mathrm{H}_{2} \mathrm{NTA}}+3 \alpha_{\mathrm{H}_{3} \mathrm{NTA}}\right)$ corresponds to the number of protons transferred. The coefficients in Table 2 indicate the percentage of the metal and ligands in solution under experimental conditions and are defined as follows (Eqs. 12-15):

$\alpha_{\mathrm{MB}}=\frac{K_{\mathrm{MB}}^{\prime}[\mathrm{B}]}{1+K_{\mathrm{MB}}^{\prime}[\mathrm{B}]}$

$\alpha_{\mathrm{HNTA}}=\frac{\left[\mathrm{HNTA}^{2-}\right]}{c_{\mathrm{H}_{3} \mathrm{NTA}}}=\frac{\left[\mathrm{H}_{3} \mathrm{O}^{+}\right]}{K_{\mathrm{a} 3} \cdot \alpha_{\text {proton }}}$

$\alpha_{\mathrm{H}_{2} \mathrm{NTA}}=\frac{\left[\mathrm{H}_{2} \mathrm{NTA}^{-}\right]}{c_{\mathrm{H}_{3} \mathrm{NTA}}}=\frac{\left[\mathrm{H}_{3} \mathrm{O}^{+}\right]^{2}}{K_{\mathrm{a} 3} \cdot K_{\mathrm{a} 2} \cdot \alpha_{\text {proton }}}$

$\alpha_{\mathrm{H}_{3} \mathrm{NTA}}=\frac{\left[\mathrm{H}_{3} \mathrm{NTA}\right]}{c_{\mathrm{H}_{3} \mathrm{NTA}}}=\frac{\left[\mathrm{H}_{3} \mathrm{O}^{+}\right]^{3}}{K_{\mathrm{a} 3} \cdot K_{\mathrm{a} 2} \cdot K_{\mathrm{a} 1} \cdot \alpha_{\text {proton }}}$

In $\mathrm{pH} 6$, the $\left(\alpha_{\mathrm{HNTA}}+2 \alpha_{\mathrm{H}_{2} \mathrm{NTA}}+3 \alpha_{\mathrm{H}_{3} \mathrm{NTA}}\right)$ calculated according to Eqs. 13-15, equals 1. This means that during the experiment the number of moles of the protons released by $1 \mathrm{~mol}$ of $\mathrm{H}_{3}$ NTA during complexation of the $\mathrm{Co}^{2+}$ or $\mathrm{Ni}^{2+}$ ions equals to 1 .

When a proton is released from a ligand during complexation a new, additional energy is generated. It is connected with the transfer of the proton from the ligand to the

Table 3 Thermodynamic parameters $\left(\log K_{\mathrm{ITC}}, \Delta H_{\mathrm{ITC}}\right)$ of the $\mathrm{Co}^{2+}$ and $\mathrm{Ni}^{2+}$ ions binding to $\mathrm{H}_{3} \mathrm{NTA}$ and the $\Delta H_{\mathrm{MB}}$ values of the metal-buffer (Mes, Caco, and Pipes) interactions in solutions of pH 6, at $298.15 \mathrm{~K}$

\begin{tabular}{llllll}
\hline Buffer & Metal ion & $\log K_{\mathrm{ITC}}(\mathrm{MNTA}) / \mathrm{M}^{-1 \mathrm{a}}$ & $\Delta H_{\mathrm{ITC}}(\mathrm{MNTA}) / \mathrm{kcal} \mathrm{mol}^{-1}$ & $\log K(\mathrm{MNTA}) / \mathrm{M}^{-1 \mathrm{~b}}$ & $\Delta H_{\mathrm{MB}}^{\mathrm{c}} / \mathrm{kcal} \mathrm{mol}^{-1}$ \\
\hline Mes & $\mathrm{Co}^{2+}$ & $6.45( \pm 0.07)$ & $+1.04( \pm 0.01)$ & $10.76( \pm 0.01)$ & 0.29 \\
Caco & $\mathrm{Co}^{2+}$ & $6.29( \pm 0.02)$ & $+4.41( \pm 0.01)$ & $10.84( \pm 0.02)$ & 1.25 \\
Pipes & $\mathrm{Co}^{2+}$ & $6.22( \pm 0.03)$ & $+1.62( \pm 0.01)$ & $11.45( \pm 0.12)$ & $0.02)$ \\
Mes & $\mathrm{Ni}^{2+}$ & $7.12( \pm 0.12)$ & $-1.50( \pm 0.01)$ & $11.86( \pm 0.07)$ & 0.40 \\
Caco & $\mathrm{Ni}^{2+}$ & $7.31( \pm 0.07)$ & $+2.01( \pm 0.01)$ & $11.11( \pm 0.07)$ & 0.63 \\
Pipes & $\mathrm{Ni}^{2+}$ & $6.49( \pm 0.12)$ & $-0.89( \pm 0.01)$ & \\
\hline
\end{tabular}

${ }^{a}$ The equilibrium binding constant $K_{\text {ITC }}$ and binding enthalpy $\Delta H_{\text {ITC }}$ for the metal- $\mathrm{H}_{3} \mathrm{NTA}$ interaction were obtained from ITC experiments by fitting binding isotherms, using nonlinear least-squares procedures, to a model that assumes a single set of identical binding sites

b The logarithms of metal- $\mathrm{H}_{3}$ NTA formation constants corrected for both buffer competition with the strong ligand $\left(\mathrm{H}_{3} \mathrm{NTA}\right)$ for the metal ion and proton competition with the metal ion for the ligand

c The enthalpies of metal-buffer interactions based on Eq. 17 
Time/min

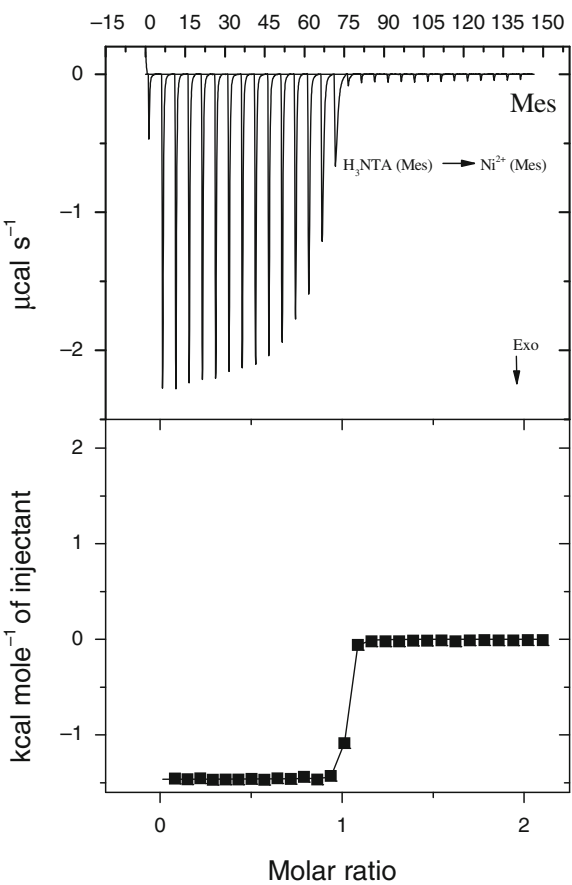

Time/min

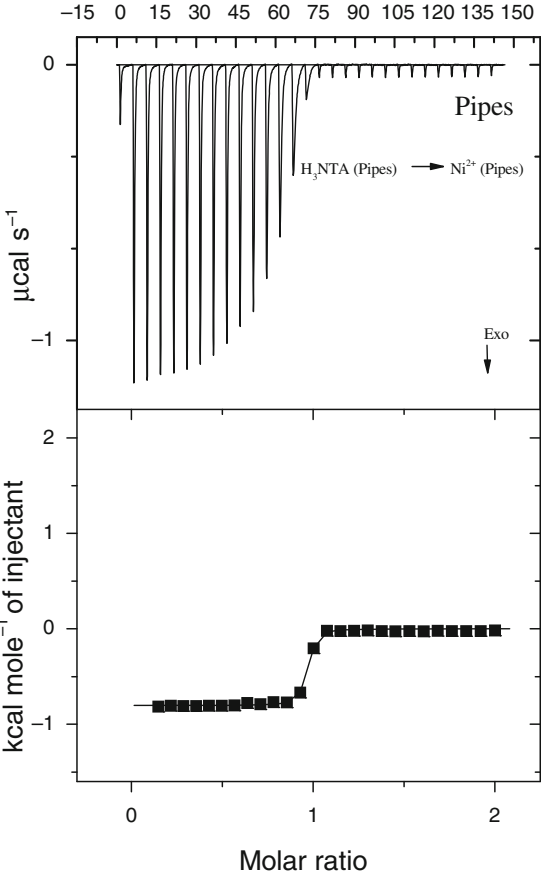

Time/min

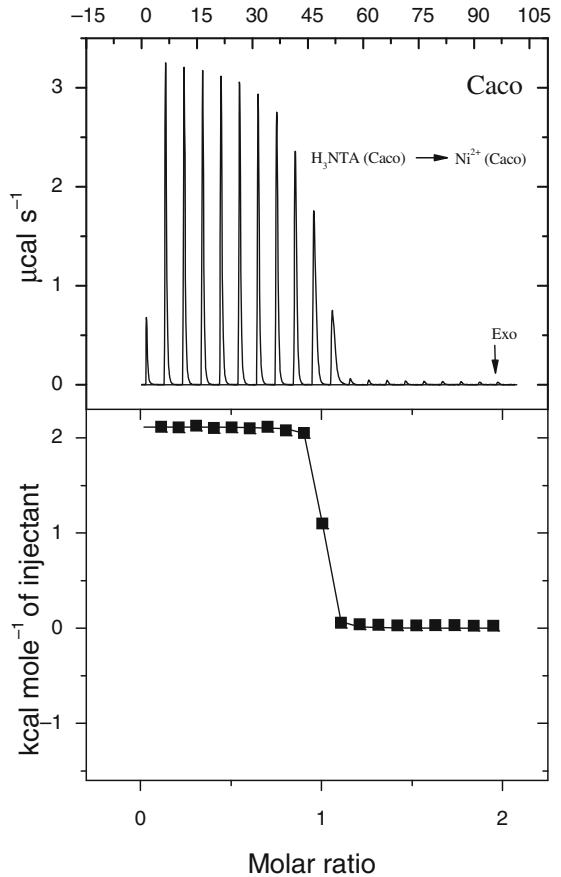

Fig. 3 Calorimetric titration isotherms of the binding interaction between $\mathrm{Ni}^{2+}$ and $\mathrm{H}_{3} \mathrm{NTA}$ in buffers with different ionization enthalpies (Mes, Pipes, Caco, $100 \mathrm{mM}$ each) of $\mathrm{pH} \mathrm{6}$, at $298.15 \mathrm{~K}$

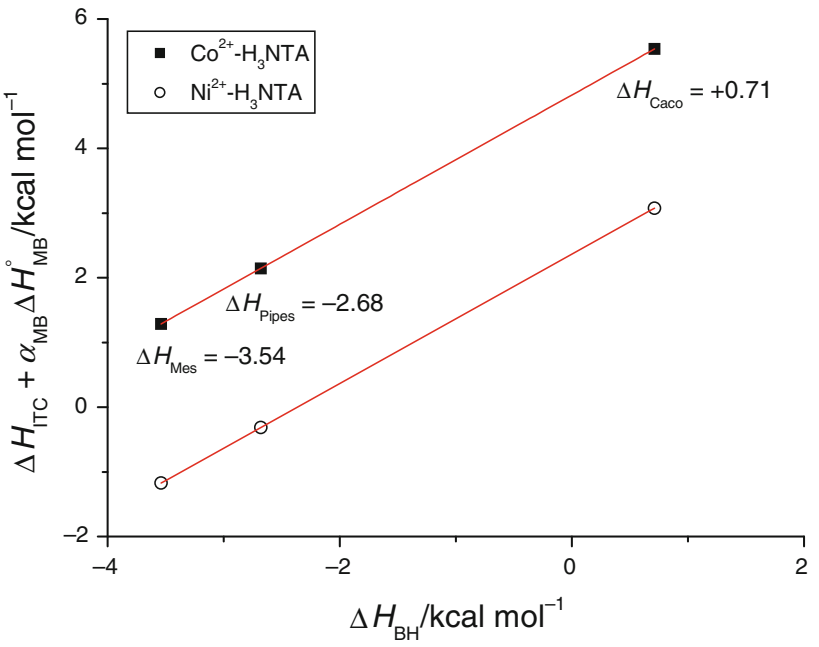

Fig. 4 Plot of $\left(\Delta H_{\mathrm{ITC}}+\alpha_{\mathrm{MB}} \Delta H_{\mathrm{MB}}^{\mathrm{o}}\right)$ versus $\Delta H_{\mathrm{BH}}^{\mathrm{o}}$ for the $\mathrm{Co}^{2+}$ and $\mathrm{Ni}^{2+}-\mathrm{H}_{3} \mathrm{NTA}$ interactions in $100 \mathrm{mM}$ Mes, Caco, and Pipes at $\mathrm{pH}$, $298.15 \mathrm{~K}$

buffer. Carrying out the ITC measurements in buffer solutions of equal $\mathrm{pH}$ but different enthalpies of proton association of its components (Mes, Caco, Pipes), $\Delta H_{\mathrm{BH}}$, made it possible to determine the enthalpy of complex formation, independent of the nature of the buffer used [16-18]. Moreover, when the enthalpy of the metal-ligand (strong ligand) reaction is known, $\Delta H_{\mathrm{MNTA}}^{\mathrm{o}}$, the metalbuffer (weak ligand) enthalpy can be calculated, $\Delta H_{\mathrm{MB}}^{\mathrm{O}}$. The observed enthalpy of binding, $\Delta H_{\mathrm{ITC}}$, obtained from
ITC titration, can be expressed by Eq. 16, which is based on Hess's law [19]:

$$
\begin{aligned}
\Delta H_{\mathrm{ITC}}= & -\alpha_{\mathrm{MB}} \Delta H_{\mathrm{MB}}^{\mathrm{o}}-\alpha_{\mathrm{HNTA}} \Delta H_{\mathrm{HNTA}}^{\mathrm{o}}-\alpha_{\mathrm{H}_{2} \mathrm{NTA}} \Delta H_{\mathrm{H}_{2} \mathrm{NTA}}^{\mathrm{o}} \\
& -\alpha_{\mathrm{H}_{3} \mathrm{NTA}} \Delta H_{\mathrm{H}_{3} \mathrm{NTA}}^{\mathrm{o}}+\left(\alpha_{\mathrm{HNTA}}+2 \alpha_{\mathrm{H}_{2} \mathrm{NTA}}\right. \\
& \left.+3 \alpha_{\mathrm{H}_{3} \mathrm{NTA}}\right) \Delta H_{\mathrm{BH}}+\Delta H_{\mathrm{MNTA}}^{\circ}
\end{aligned}
$$

Finally, the metal-buffer enthalpy, $\Delta H_{\mathrm{MB}}^{\mathrm{o}}$, can be found by transformation of Eq. 16:

$$
\begin{aligned}
\Delta H_{\mathrm{MB}}^{\circ}= & {\left[-\Delta H_{\mathrm{ITC}}-\alpha_{\mathrm{HNTA}} \Delta H_{\mathrm{HNTA}}^{\circ}-\alpha_{\mathrm{H}_{2} \mathrm{NTA}} \Delta \mathrm{H}_{\mathrm{H}_{2} \mathrm{NTA}}^{\circ}\right.} \\
& -\alpha_{\mathrm{H}_{3} \mathrm{NTA}} \Delta H_{\mathrm{H}_{3} \mathrm{NTA}}^{\circ}+\left(\alpha_{\mathrm{HNTA}}+2 \alpha_{\mathrm{H}_{2} \mathrm{NTA}}\right. \\
& \left.\left.+3 \alpha_{\mathrm{H}_{3} \mathrm{NTA}}\right) \Delta H_{\mathrm{BH}}+\Delta H_{\mathrm{MNTA}}^{\circ}\right] / \alpha_{\mathrm{MB}}
\end{aligned}
$$

To do this, the $\Delta H_{\text {ITC }}$ of $\mathrm{Co}^{2+}-\mathrm{H}_{3} \mathrm{NTA}$ and $\mathrm{Ni}^{2+}-$ $\mathrm{H}_{3}$ NTA interactions were measured in Mes, Caco, and Pipes buffered solutions. The obtained results $\left(\log K_{\text {ITC }}\right.$, $\left.\Delta H_{\mathrm{ITC}}\right)$ as well as the $\Delta H_{\mathrm{MB}}^{\mathrm{o}}$ values calculated from Eq. 17 are listed in Table 3. Representative binding isotherms for $\mathrm{Ni}-\mathrm{H}_{3} \mathrm{NTA}$ interactions are shown in Fig. 3. Calorimetric titration isotherms of the binding interaction between $\mathrm{Co}^{2+}$ and $\mathrm{H}_{3} \mathrm{NTA}$ are presented in the Supplementary Material (Fig. S1). The proton-association enthalpies of buffers, $\Delta H_{\mathrm{BH}}\left(\mathrm{H}^{+}+\mathrm{B}^{-}=\mathrm{HB}^{ \pm}\right)$, used in this study are +0.71 , -2.68 , and $-3.54 \mathrm{kcal} \mathrm{mol}^{-1}$ for Caco, Pipes, and Mes, respectively [20]. The metal- $\mathrm{H}_{3} \mathrm{NTA}$ formation constants, the enthalpies of metal- $\mathrm{H}_{3} \mathrm{NTA}$ interactions, $\Delta H_{\mathrm{MNTA}}^{\mathrm{o}}$, as well as the enthalpies of the proton association to the ligand 
used in the calculations were taken from literature $[15,21]$. They are listed below:

$$
\begin{aligned}
& \log K_{\text {CoNTA }}\left(\mathrm{Co}^{2+}+\mathrm{NTA}^{3-}=\mathrm{CoNTA}^{-}\right)=10.5 \\
& \log K_{\mathrm{NiNTA}}\left(\mathrm{Ni}^{2+}+\mathrm{NTA}^{3-}=\mathrm{NiNTA}^{-}\right)=11.4 \\
& \Delta H_{\mathrm{CoNTA}}^{\circ}\left(\mathrm{Co}^{2+}+\mathrm{NTA}^{3-}=\mathrm{CoNTA}^{-}\right) \\
& =-0.07 \mathrm{kcal} \mathrm{mol}^{-1} \Delta H_{\mathrm{NiNTA}}^{\circ}\left(\mathrm{Ni}^{2+}+\mathrm{NTA}^{3-}=\mathrm{NiNTA}^{-}\right) \\
& =-2.53 \mathrm{kcal} \mathrm{mol}^{-1} \Delta H_{\mathrm{HNTA}}^{\circ}\left(\mathrm{NTA}^{3-}+\mathrm{H}^{+}=\mathrm{HNTA}^{2-}\right) \\
& =-4.90 \mathrm{kcal} \mathrm{mol}^{-1} \Delta H_{\mathrm{H}_{2} \mathrm{NTA}}^{\circ}\left(\mathrm{HNTA}^{2-}+\mathrm{H}^{+}=\mathrm{H}_{2} \mathrm{NTA}^{-}\right) \\
& =+0.80 \mathrm{kcal} \mathrm{mol}^{-1} \Delta H_{\mathrm{H}_{3} \mathrm{NTA}}^{\circ}\left(\mathrm{H}_{2} \mathrm{NTA}^{-}+\mathrm{H}^{+}=\mathrm{H}_{3} \mathrm{NTA}\right) \\
& =+0.75 \mathrm{kcal} \mathrm{mol}^{-1}
\end{aligned}
$$

The $\Delta H_{\text {ITC }}$ determined from the ITC experiment depends on the nature of the buffer solution in which the measurement was carried out (Table 3). The drop of the $\Delta H_{\text {ITC }}$ value with decreasing buffer association enthalpy, $\Delta H_{\mathrm{BH}}$, shows that during complexation of the metal ions, the protons are transferred from the ligand to the buffer. For this reason, energetic effects due to metal-ligand interaction in buffer solutions of negative association enthalpies (Mes, Pipes) are reduced by the energy (heat) released during proton binding to a buffer component. With the Caco buffer of positive association enthalpy $\left(+0.71 \mathrm{kcal} \mathrm{mol}^{-1}\right)$, the proton transfer during complexation of the metal ions results in an increase in $\Delta H_{\mathrm{ITC}}$. It is especially seen in the case of $\mathrm{Ni}^{2+}-\mathrm{H}_{3} \mathrm{NTA}$ interactions, where $\Delta H_{\text {ITC }}$ is negative when titration is carried out in the Mes and Pipes buffer solutions, then changes to positive in the Caco buffer (Table 3; Fig. 3).

Equation 16 can be transformed to the linear relationship $y=a+b x$ (Eq. 18) as seen below:

$$
\begin{aligned}
\Delta H_{\mathrm{ITC}}+\alpha_{\mathrm{MB}} \Delta H_{\mathrm{MB}}^{\circ} & =\left(\alpha_{\mathrm{HNTA}}+2 \alpha_{\mathrm{H}_{2} \mathrm{NTA}}+3 \alpha_{\mathrm{H}_{3} \mathrm{NTA}}\right) \\
& \times \Delta H_{\mathrm{BH}}^{\circ}+\Delta H_{\mathrm{MNTA}}^{\circ}-\alpha_{\mathrm{HNTA}} \Delta H_{\mathrm{HNTA}}^{\circ} \\
& -\alpha_{\mathrm{H}_{2} \mathrm{NTA}} \Delta_{\mathrm{H}_{2} \mathrm{NTA}}^{\circ}-\alpha_{\mathrm{H}_{3} \mathrm{NTA}} \Delta H_{\mathrm{H}_{3} \mathrm{NTA}}^{\circ}
\end{aligned}
$$

where $y=\Delta H_{\mathrm{ITC}}+\alpha_{\mathrm{MB}} \Delta H_{\mathrm{MB}}^{\mathrm{o}}, \quad a=\Delta H_{\mathrm{MNTA}}^{\mathrm{o}}-\alpha_{\mathrm{HNTA}}$ $\Delta H_{\mathrm{HNTA}}^{\mathrm{o}}-\alpha_{\mathrm{H}_{2} \mathrm{NTA}} \Delta H_{\mathrm{H}_{2} \mathrm{NTA}}^{\mathrm{o}}-\alpha_{\mathrm{H}_{3} \mathrm{NTA}} \Delta H_{\mathrm{H}_{3} \mathrm{NTA}}^{\mathrm{o}}, b=\alpha_{\mathrm{HNTA}}$ $+2 \alpha_{\mathrm{H}_{2} \mathrm{NTA}}+3 \alpha_{\mathrm{H}_{3} \mathrm{NTA}}$ - the number of proton transferred, and $x=\Delta H_{\mathrm{BH}}^{\mathrm{o}}$-the proton-association enthalpy of buffer.

The plots of $\left(\Delta H_{\mathrm{ITC}}+\alpha_{\mathrm{MB}} \Delta H_{\mathrm{MB}}^{\mathrm{o}}\right)$ versus $\Delta H_{\mathrm{BH}}^{\mathrm{o}}$ for the $\mathrm{Co}^{2+}$ and the $\mathrm{Ni}^{2+}$ complexes are shown in Fig. 4. From a slope of the relationship described by Eq. 18, the number of protons transferred was determined and equaled 0.999 $( \pm 0.001)$ for both the $\mathrm{Co}^{2+}$ and the $\mathrm{Ni}^{2+}-\mathrm{H}_{3} \mathrm{NTA}$ complexes. These values agree with those calculated using Eqs. 13-15.
When the enthalpy of metal (M)-ligand (L) interaction is unknown, $\Delta H_{\mathrm{ML}}^{\mathrm{o}}$, it can be determined, for triprotonated ligand $\left(\mathrm{H}_{3} \mathrm{~L}\right)$, using the value at the point of interception of the plot presented in Fig. $4, \Delta H_{\mathrm{ML}}^{\mathrm{o}}-\alpha_{\mathrm{HL}} \Delta H_{\mathrm{HL}}^{\mathrm{o}}-$ $\alpha_{\mathrm{H}_{2} \mathrm{~L}} \Delta H_{\mathrm{H}_{2} \mathrm{~L}}^{\mathrm{o}}-\alpha_{\mathrm{H}_{3} \mathrm{~L}} \Delta H_{\mathrm{H}_{3} \mathrm{~L}}^{\mathrm{o}}$.

\section{Conclusions}

ITC and PT methods have successfully been applied to determine thermodynamic parameters $\left(K_{\mathrm{MB}}, \Delta H_{\mathrm{MB}}\right)$ for complexation reactions of $\mathrm{Co}^{2+}$ and $\mathrm{Ni}^{2+}$ ions with buffer substances Mes, Caco, and Pipes. The metal-buffer formation constants $K_{\mathrm{MB}}$ were determined by PTs. The stability of the examined complexes increased in the following directions: CoMes $\left(\log K_{\mathrm{CoMes}}=2.04\right)<\mathrm{CoCaco}\left(\log K_{\mathrm{CoCaco}}\right.$ $=2.30)<$ CoPipes $\quad\left(\log K_{\text {CoPipes }}=3.12\right) \quad$ and NiMes $\left(\log K_{\mathrm{NiMes}}=2.06\right)<\mathrm{NiCaco} \quad\left(\log K_{\mathrm{NiCaco}}=2.33\right)<\mathrm{Ni}-$ Pipes $\left(\log K_{\mathrm{NiPipes}}=3.20\right)$. Furthermore, these values were extrapolated to the conditions under study (pH 6) and used for calculation of the enthalpies of metal-buffer interactions $\Delta H_{\mathrm{MB}}$. The enthalpies, $\Delta H_{\mathrm{MB}}$, were determined indirectly by ITC displacement titration using $\mathrm{H}_{3} \mathrm{NTA}$ as a strongbinding, competitive ligand. Based on Hess's law the following values were obtained: $\Delta H_{\mathrm{CoMes}}=0.29 \mathrm{kcal} \mathrm{mol}^{-1}$, $\Delta H_{\text {CoPipes }}=0.58 \mathrm{kcal} \mathrm{mol}^{-1}, \Delta H_{\text {CoCaco }}=1.25 \mathrm{kcal} \mathrm{mol}^{-1}$, $\Delta H_{\mathrm{NiMes}}=0.40 \mathrm{kcal} \mathrm{mol}^{-1}, \Delta H_{\mathrm{NiPipes}}=0.63 \mathrm{kcal} \mathrm{mol}^{-1}$, and $\Delta H_{\mathrm{NiCaco}}=1.18 \mathrm{kcal} \mathrm{mol}^{-1}$.

The ITC method is a useful tool for investigation of the metal-ligand interactions in solution. It can be used as a supportive or alternative technique for other methods. However, the determination of thermodynamic parameters is not always easy, especially when metal ions are involved in the systems under study. During analysis of calorimetric data the experimental conditions must be taken into consideration. The most important energetic effects that are not connected with the metal-ligand interactions are the enthalpy of proton dissociation from the ligand, the enthalpy of buffer ionization as well as the enthalpy formation, and the stability constant of metal-buffer complex. In this article, it has been presented how to include these factors during calorimetric data analysis.

Acknowledgements This study is supported by grant for Young Scientists 2012 from the University of Gdańsk (DW No. 538-82321076-12) and from the National Science Centre (N N204 136238).

Open Access This article is distributed under the terms of the Creative Commons Attribution License which permits any use, distribution, and reproduction in any medium, provided the original author(s) and the source are credited. 


\section{References}

1. Ladbury JE, Doyle ML. Biocalorimetry. 2. Application of calorimetry in the biological sciences. West Sussex: Wiley; 2004.

2. Gaisford S, O'Neill MAA. Pharmaceutical isothermal calorimetry. New York: Informa Healthcare USA Inc.; 2007.

3. Zhang Y, Akilesh S, Wilcox DE. Isothermal titration calorimetry measurements of $\mathrm{Ni}(\mathrm{II})$ and $\mathrm{Cu}(\mathrm{II})$ binding to His, GlyGlyHis, HisGlyHis, and bovine serum albumin: a critical evaluation. Inorg Chem. 2000;39:3057-64.

4. Hong L, William DB, Hatcher LQ, Simon J. Determining thermodynamic parameters from isothermal calorimetric isotherms of the binding of macromolecules to metal cations originally chelated by a weak ligand. J Phys Chem B. 2008;112:604-11.

5. Grossoehme NE, Akilesh S, Guerinot ML, Wilcox DE. Metal binding thermodynamics of the histidine-rich sequence from the metal-transport protein IRT1 of Arabidopsis thaliana. Inorg Chem. 2006;45:8500-8.

6. Rezaei G, Mirzaie M. A high performance methods for thermodynamic study on the binding of copper ion and glycine with Alzheimer's amyloid $\beta$ peptide. J Thermal Anal Calorim. 2009; 96:631-5.

7. Wyrzykowski D, Zarzeczańska D, Jacewicz D, Chmurzyński L. Investigation of copper(II) complexation by glycylglycine using isothermal titration calorimetry. J Thermal Anal Calorim. 2011; 105:1043-7.

8. Good NE, Winget GD, Winter W, Connoly TN, Izawa S, Singh RMM. Hydrogen ion buffers for biological research. Biochemistry. 1966;4:467-77.

9. Christensen T, Gooden DM, Kung JE, Toone EJ. Additivity and the physical basis of multivalency effects: a thermodynamic investigation of the calcium EDTA interaction. J Am Chem Soc. 2003;125:7357-66.

10. Brandariz I, Barriada J, Vilarino T, de Vicente MS. Comparison of several calibration procedures for glass electrodes in proton concentration. Monatsh Chem. 2004;135:1475-88.
11. Kostrowicki J, Liwo A. A general method for the determination of the stoichiometry of unknown species in multicomponent systems from physicochemical measurements. Comput Chem. 1987;11:195-210.

12. Kostrowicki J, Liwo A. Determination of equilibrium parameters by minimization of an extended sum of squares. Talanta. 1990;37:645-50.

13. Kumita H, Jitsukawa K, Masuda H, Einaga H. Structures and electrochemical properties of the $\mathrm{Co}(\mathrm{III})$ ternary complexes containing $\mathrm{NO}_{3}$-type tripodal tetradentate ligands and amino acids: effect of the outer coordination sphere on the electrochemical properties. Inorg Chim Acta. 1998;283:160-6.

14. Khalil MMH, Ismail EH, Azim SA, Souaya ER. Synthesis, characterization, and thermal analysis of ternary complexes of nitrilotriacetic acid and alanine or phenylalanine with some transition metals. J Therm Anal Calorim. 2010;101:129-35.

15. Sillen LG, Martel AE. Stability constants of metal-ion complexes. London: The Chemical Society; 1966.

16. Baker BM, Murphy KP. Evaluation of linked protonation effects in protein binding reactions using isothermal titration calorimetry. Biophys J. 1996;71:2049-55.

17. Wyrzykowski D, Chmurzyński L. Thermodynamics of citrate complexation with $\mathrm{Mn}^{2+}, \mathrm{Co}^{2+}, \mathrm{Ni}^{2+}$ and $\mathrm{Zn}^{2+}$ ions. $\mathrm{J}$ Therm Anal Calorim. 2010;102:61-4.

18. Wyrzykowski D, Czupryniak J, Ossowski T, Chmurzyński L. Thermodynamic interactions of the alkaline earth metal ions with citric acid. J Therm Anal Calorim. 2010;102:149-54.

19. Grossoehme NE, Spuches AM, Wilcox DE. Application of isothermal titration calorimetry in bioinorganic chemistry. J Biol Inorg Chem. 2010;15:1183-91.

20. Goldberg RN, Kishore N, Lennen RM. Thermodynamic quantities for the ionization reactions of buffers. J Phys Chem Ref Data. 2002;31:231-70.

21. Christensen JJ, Reed MI. Handbook of metal ligand heats and related thermodynamic quantities. New York: Marcel Dekker, Inc.; 1983. 